\title{
Front Matter: Volume 8128
}

, "Front Matter: Volume 8128," Proc. SPIE 8128, Current Developments in Lens Design and Optical Engineering XII; and Advances in Thin Film Coatings VII, 812801 (10 October 2011); doi: 10.1117/12.912649

SPIE Event: SPIE Optical Engineering + Applications, 2011, San Diego, California, United States 


\section{PROCEEDINGS OF SPIE}

\section{Current Developments in Lens Design and Optical Engineering XII; and Advances in Thin Film Coatings VII}

R. Barry Johnson

Virendra N. Mahajan

Simon Thibault

Editors

22-23 August 2011

San Diego, California, United States

Sponsored and Published by

SPIE 
The papers included in this volume were part of the technical conference cited on the cover and title page. Papers were selected and subject to review by the editors and conference program committee. Some conference presentations may not be available for publication. The papers published in these proceedings reflect the work and thoughts of the authors and are published herein as submitted. The publisher is not responsible for the validity of the information or for any outcomes resulting from reliance thereon.

Please use the following format to cite material from this book:

Author(s), "Title of Paper," in Current Developments in Lens Design and Optical Engineering XII; and Advances in Thin Film Coatings VII, edited by R. Barry Johnson, Virendra N. Mahajan, Simon Thibault, Proceedings of SPIE Vol. 8128 (SPIE, Bellingham, WA, 2011) Article CID Number.

ISSN 0277-786X

ISBN 9780819487384

Published by

SPIE

P.O. Box 10, Bellingham, Washington 98227-0010 USA

Telephone +1 3606763290 (Pacific Time) · Fax +1 3606471445

SPIE.org

Copyright (C) 2011, Society of Photo-Optical Instrumentation Engineers

Copying of material in this book for internal or personal use, or for the internal or personal use of specific clients, beyond the fair use provisions granted by the U.S. Copyright Law is authorized by SPIE subject to payment of copying fees. The Transactional Reporting Service base fee for this volume is $\$ 18.00$ per article (or portion thereof), which should be paid directly to the Copyright Clearance Center (CCC), 222 Rosewood Drive, Danvers, MA 01923. Payment may also be made electronically through CCC Online at copyright.com. Other copying for republication, resale, advertising or promotion, or any form of systematic or multiple reproduction of any material in this book is prohibited except with permission in writing from the publisher. The CCC fee code is 0277-786X/11/ \$18.00.

Printed in the United States of America.

Publication of record for individual papers is online in the SPIE Digital Library.

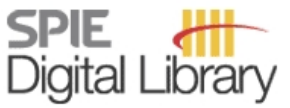

SPIEDigitalLibrary.org

Paper Numbering: Proceedings of SPIE follow an e-First publication model, with papers published first online and then in print and on CD-ROM. Papers are published as they are submitted and meet publication criteria. A unique, consistent, permanent citation identifier (CID) number is assigned to each article at the time of the first publication. Utilization of CIDs allows articles to be fully citable as soon as they are published online, and connects the same identifier to all online, print, and electronic versions of the publication. SPIE uses a six-digit CID article numbering system in which:

- The first four digits correspond to the SPIE volume number.

- The last two digits indicate publication order within the volume using a Base 36 numbering system employing both numerals and letters. These two-number sets start with $00,01,02,03,04$, $05,06,07,08,09,0 A, 0 B \ldots 0 Z$, followed by 10-1Z, 20-2Z, etc.

The CID number appears on each page of the manuscript. The complete citation is used on the first page, and an abbreviated version on subsequent pages. Numbers in the index correspond to the last two digits of the six-digit CID number. 


\section{Contents}

$\checkmark$ Conference Committee

vii Introduction

ix The history of telescopes and binoculars: an engineering perspective (Plenary Paper) [8129-100]

J. E. Greivenkamp, D. L. Steed, College of Optical Sciences, The Univ. of Arizona (United States)

\section{SESSION 1 LENS DESIGN AND OPTICAL ENGINEERING I}

812802 Cryogenic lens design case study: Gemini Planet Imager spectrograph (Invited Paper) [8128-01]

S. Thibault, Univ. Laval (Canada)

812804 Development of multi-spectral lenses for thermal imaging technique [8128-03]

S. N. Bezdidko, Open Joint-Stock Co. (Russian Federation); E. I. Morozova, The Freelancers, Moscow (Russian Federation); Y. A. Roy, Open Joint-Stock Co. (Russian Federation)

\section{SESSION 2 ADVANCES IN SSL}

812805 Optical transmittance of high-efficiency cavity with photon recycling [8128-04]

C.-C. Lin, X.-H. Lee, W.-T. Chien, H.-X. Chen, C.-C. Sun, National Central Univ. (Taiwan)

812806 Optical design of the focal adjustable flashlight based on a power white-LED [8128-05] J.-Y. Cai, Y.-C. Lo, C.-C. Sun, National Central Univ. (Taiwan)

812807 High energy-efficient $B+R$ LED beam shaping with micro-lens diffuser for agricultural lighting [8128-06]

Y.-Y. Chang, X.-H. Lee, C.-C. Sun, National Central Univ. (Taiwan)

\section{SESSION 3 LENS DESIGN AND OPTICAL ENGINEERING II}

812808 Range-balancing the Large Binocular Telescope (Invited Paper) [8128-07]

A. Rakich, D. Thompson, O. P. Kuhn, Large Binocular Telescope Observatory (United States)

812809 Advanced optical design for DNA sequencing systems [8128-08]

K. Sobolev, A. Joobeur, ASML (United States); C. Uhrich, Complete Genomics, Inc. (United States); D. Aziz, Midbar West, Inc. (United States)

8128 OA Development and experimental verification of an intraocular scattering model [8128-10]

C.-J. Jiang, T.-S. Jhong, Y.-C. Chen, C.-C. Sun, National Central Univ. (Taiwan) 
$8128 \mathrm{OB}$ Linear systems formulation of image analysis in the presence of both aberrations and surface scatter [8128-22]

N. Choi, J. E. Harvey, CREOL, The College of Optics and Photonics, Univ. of Central Florida (United States)

\section{SESSION 4 THIN FILM OPTICAL COATING}

8128 OD Transmission losses in infrared anti-reflection coatings due to water absorption [8128-12] C. J. Panetta, P. D. Fuqua, C.-T. Chu, J. D. Barrie, The Aerospace Corp. (United States)

\section{SESSION 5 DESIGN METHODS AND TECHNIQUES}

8128 OE Design of a free-form lens system for short distance projection (Invited Paper) [8128-13] B. Yang, K. Lu, W. Zhang, Univ. of Shanghai for Science and Technology (China); F. Dai, Zhejiang Sunny Optics Co., Ltd (China)

8128 OF Progress in the SMS design method for imaging optics [8128-14]

W. Lin, Univ. Politécnica de Madrid (Spain); P. Benítez, J. C. Miñano, Univ. Politécnica de Madrid (Spain) and Light Prescriptions Innovators, LLC (United States); J. Infante, G. Biot, Univ. Politécnica de Madrid (Spain)

8128 0G Distributed wavefront coding for wide angle imaging system [8128-15] M. Larivière-Bastien, H. Zhang, S. Thibault, Univ. Laval (Canada)

$8128 \mathrm{OH} \quad$ Progressive addition lens design by optimizing NURBS surface [8128-16] Y.-L. Liu, W.-Y. Hsu, National Taiwan Univ. (Taiwan); Y.-C. Cheng, National Applied Research Labs. (Taiwan); G.-D. Su, National Taiwan Univ. (Taiwan)

\section{POSTER SESSION}

$81280 \mathrm{Ol}$ Testing and design of a low-cost large scale solar simulator [8128-17] Q. Meng, Chang'an Univ. (China) and Xi'an Jiaotong Univ. (China); Y. Wang, Xi'an Jiaotong Univ. (China)

$8128 \mathrm{JJ}$ Effects of substrate heating and vacuum annealing on optical and electrical properties of alumina-doped ZnO films deposited by DC magnetron sputtering [8128-18]

C.-J. Tang, C.-Y. Wang, C.-C. Jaing, Minghsin Univ. of Science and Technology (Taiwan)

8128 OK The research of relationships between residual stress and columnar angles in oblique deposition of magnesium fluoride thin films [8128-19]

C.-C. Jaing, Minghsin Univ. of Science and Technology (Taiwan); M.-C. Liu, W.-H. Cho, National Central Univ. (Taiwan); C.-J. Tang, Minghsin Univ. of Science and Technology (Taiwan); Y.-Y. Liou, Chienkuo Technology Univ. (Taiwan); J.-Y. Wang, Minghsin Univ. of Science and Technology (Taiwan); C.-C. Lee, National Central Univ. (Taiwan)

$8128 \mathrm{OL}$ The design of beam shaping focused lens applied in solar energy concentration [8128-20] S.-H. Ma, C.-H. Lee, Feng Chia Univ. (Taiwan); Y.-P. Lee, J.-H. Wu, Ming Chuan Univ. (Taiwan); C.-M. Tseng, Feng Chia Univ. (Taiwan)

Author Index 


\title{
Conference Committee
}

\author{
Program Track Chairs
}

R. John Koshel, Photon Engineering LLC (United States) and College of Optical Sciences, The University of Arizona (United States)

José Sasián, College of Optical Sciences, The University of Arizona (United States)

\section{Conference Chairs}

R. Barry Johnson, Alabama A\&M University (United States) and Consultant (United States)

Virendra N. Mahajan, The Aerospace Corporation (United States)

Simon Thibault, ImmerVision (Canada) and University Laval (Canada)

\section{Program Committee}

Julie Bentley, University of Rochester (United States)

Florian Bociort, Technische Universiteit Delft (Netherlands)

Robert M. Bunch, Rose-Hulman Institute of Technology (United States)

Pierre H. Chavel, Laboratoroire Charles Fabry (France)

Chung-Tse Chu, The Aerospace Corporation (United States)

Apostolos Deslis, JENOPTIK Optical Systems, Inc. (United States)

José Antonio Díaz-Navas, Universidad de Granada (Spain)

Alexander V. Goncharov, National University of Ireland, Galway (Ireland)

James E. Harvey, CREOL, The College of Optics and Photonics, University of Central Florida (United States)

Lakshminarayan Hazra, The Optical Society of India (India) and University of Calcutta (India)

Irina L. Livshits, Saint-Petersburg State University of Information Technologies, Mechanics and Optics (Russian Federation)

Michael Mandina, Optimax Systems, Inc. (United States)

Pantazis Mouroulis, Jet Propulsion Laboratory (United States)

Ching-Cherng Sun, National Central University (Taiwan)

Yuzuru Takashima, Stanford University (United States)

Jennifer A. Turner-Valle, Ball Aerospace \& Technologies Corporation (United States)

Sergio Vázquez-Montiel, Instituto Nacional de Astrofísica, Óptica y Electrónica (Mexico)

Yongtian Wang, Beijing Institute of Technology (China)

Andrew P. Wood, Qioptiq Ltd. (United Kingdom)

Maria Josefa Yzuel, Universitat Autònoma de Barcelona (Spain) 


\section{Session Chairs}

1 Lens Design and Optical Engineering I

Virendra N. Mahajan, The Aerospace Corporation (United States)

2 Advances in SSL

Ching-Cherng Sun, National Central University (Taiwan)

3 Lens Design and Optical Engineering II

James E. Harvey, CREOL, The College of Optics and Photonics, University of Central Florida (United States)

$4 \quad$ Thin Film Optical Coating

Simon Thibault, University Laval (Canada)

5 Design Methods and Techniques

Pantazis Mouroulis, Jet Propulsion Laboratory (United States) 


\section{Introduction}

The Current Developments in Lens Design and Optical Engineering conference again included Advances in Thin Film Coatings. The proceedings comprises a total of 18 papers with four of the papers having been presented in a poster session on one day, and the other 14 were presented as oral papers on a second day in five sessions. About half of the authors are from North America. Taiwan was strongly represented with eight papers. Only two papers were from Europe, perhaps because the Optical System Design conference was held in France only two weeks later. As in the past, the papers cover a broad range of subjects, as is evident by an examination of the Table of Contents. Current Developments in Lens Design and Optical Engineering serves the multi-faceted discipline and the multi-talented individuals that dedicate themselves to this field.

\section{R. Barry Johnson Virendra N. Mahajan Simon Thibault}


Downloaded From: https://www.spiedigitallibrary.org/conference-proceedings-of-spie on 26 Apr 2023

Terms of Use: https://www.spiedigitallibrary.org/terms-of-use 